\title{
EVALUTION OF ANTIMICROBIAL ACTIVITY OF PARTIAL PURIFIED BACTERIOCIN FROM LOCAL ISOLATE OF BACILLUS LICHENIFORIMS HJ2020 MT192715.1
}
H. A. Jebur
J. M. Auda
Assist. prof.
Assist. prof.

Food Sciences Dept. / College of Agricultural Engineering Sciences / University of Baghdad E.mail: dr_hameedm59@yahoo.com ABSTRACT

This study was aimed to produce bacteriocin from Bacillus. licheniformis isolated from local soil of corn and sunflower fields and using as antimicrobial agent. Fourteen of local isolates of Bacillus sp. were obtained and ability of these isolates for growth on Brain heart infusion agar (BHI) at $55^{\circ} \mathrm{C}$ were tested. Isolate $\mathrm{C} 4$ was revealed high growth density in comparison with other isolates. Isolate C4 was identified as Bacillus licheniformis according to morphological, cultural and biochemical tests, Moreover genetic analysis for 16S rRNA gene and given accession number MT192715.1 in GenBank of NCBI . Production of bacteriocin from this isolate was carried out in Luria Broth (LB) and partially purified by precipitation with 30-70 \% saturation of ammonium sulfate followed by concentrated using poly ethylene glycol (PEG).The antimicrobial activity of partially purified bacteriocin was assayed against many species of food spoilage microorganism. Results were revealed that anitimicrobial activity of bacteriocin were between $(0-360)$ units / $\mathrm{ml}$. Stability of antimicrobial activity of partially purified bacteriocin toward Staphylococcus aureus were tested after incubation at different values of $\mathrm{pH}$, temperature and some of enzyme which included proteolytic enzymes, $\alpha$ amylase and lipase .The results indicated that residual inhibition activity of bacteriocin were varied according to conditions of incubation and type of treatment .

Key words: 16S rRNA, GenBank MT192715.1, Sunflower soil, Corn soil.

جبر و عودة

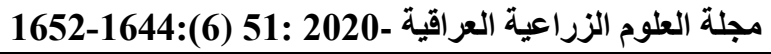

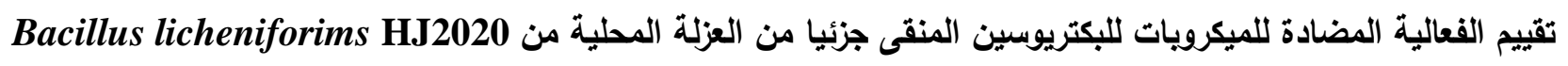
MT192715.1

\begin{tabular}{|c|c|}
\hline جاسم محمد عودة & حميا عبود جبر \\
\hline أستاذ مساعد & أستاذ مساعد \\
\hline
\end{tabular}

المستخلص

هافت الاراسة الحاليه الى انتاج البكتريوسين من بكتريا . Bacillus licheniformis المعزولة من الترب المحلية لحقول نبات الذرة الصفراء وحقول زهرة الثمس واستخدامه كمضاد للميكرويات التي تسبب تلف الغذاء ـ تم الحصول على 14 عزلة محلية من البكتريا

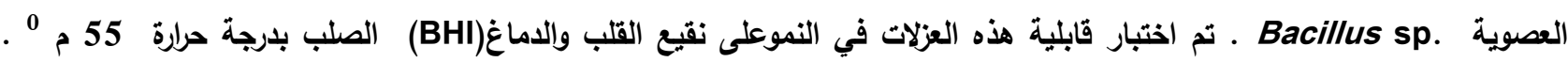

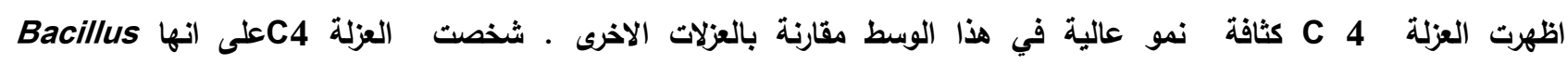

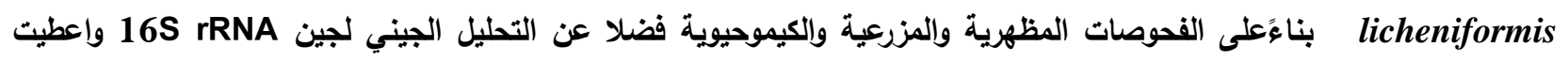

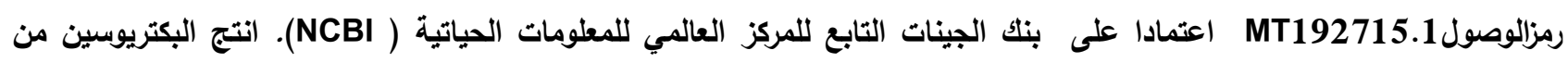
العزلة المنتخبة وياستخدام وسط(Luria Broth (LB) ، ونقي جزئيا بالترسيب باستخدام كبريتات الامونيوم بنسبة اشباع 30 - 30 -

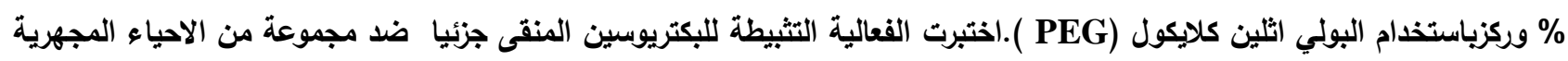

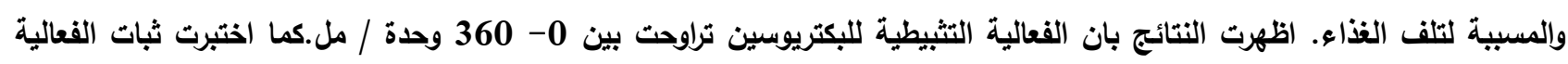
التثبطية للبكتريوسين المنقى على بكتريا المكورات العنقودية الذهبية Staphylococcus aureus بعد حضنه بارقام هيدروجينية وحرارية مختلفة ومع عدد من الانزيمات شملت على البروتيزات والالفا اميليز واللايبيز،اوضحت النتائج ان الفعالية التثبيطية المتبقية

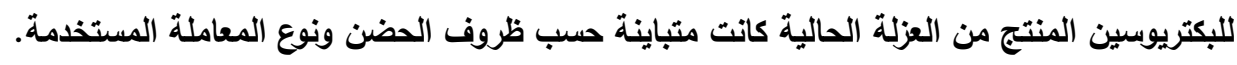

الكلمات المفتاحية : 16S rRNA ; GenBank MT192715.1 ; Sunflower soil , Corn soil 


\section{INTRODUCTION}

Bacillus licheniformis is a bacterium commonly found in the soil, It is a rod to elliptical or cylindrical shape with length of $1.5-3 \mu \mathrm{m}$ and width of $0.6-0.8 \mu \mathrm{m}$. It is central spore forming, gram-positive , optimal growth temperature is around 50 to $55{ }^{\circ} \mathrm{C}$, though it can survive at much higher temperatures. It can exist in a dormant spore form to resist harsh environments, or in a vegetative state when conditions are good. Colony on agar become opaque with dull to rough surface, irregular edges, creamy color and somewhat sticky. It can grow in aerobic and anaerobic conditions. It can produce acid and weakly positive gas from glucose, it can hydrolyze starch, reduce $\mathrm{NO}_{3}^{-}$to $\mathrm{NO}_{2}^{-}$and liquefication of nutrient gelatin $(7,18)$. Bacillus licheniformis has proved itself as a multipurpose organism and has gained popularity along with $B$. subtilis . It is most commonly found in soil ( 9 ). This isolate was used to produce a polypeptide antibiotic known as bacteriocin as well as production of commercially feasible quantities of different industrial enzymes $(11,20)$. B. licheniformis is capable of producing bacteriocins in aerobic conditions $(2,16)$, Moreover at anaerobic conditions against anaerobic microorganisms ( 24 ). Production of antimicrobial peptides is widespread among diverse bacteria ( 6 ). Most known bacteriocin producing Bacillus strains are either from soil or food. Such as bacteriocin produced by Bacillus cereus isolated from food ( 22 ) and those that produced by Bacillus cereus $8 \mathrm{~A}$ isolated from soil ( 5 ). Keeping the significance of multiple uses of Bacillus licheniformis in view, present study was designed to isolate strain of Bacillus from Iraqi soil for the production of bacteriocin, then evaluate and characterize the produced bacteriocin as antimicrobial agent .

\section{MATERIALS AND METHODS} Media and chemical reagents

All medium such as nutrient agar, nutrient broths, Brain Heart Infusion (BHI) agar, BHI broth, Lurain broth (LB), De Man, Rogosa and Sharpe agar (MRS) agar, Potato dextrose agar and MacConkey agar were purchased from HiMedia Biosciences company (india). other chemicals used throughout study were commercial products of highest purity grade and purchased from Sigma Chemicals Co. Millipore membranefilters $0.45 \mu \mathrm{m}$ were purchased from Sigma-Aldrich company. Solutions were prepared in de-ionized pure water from Al-Joud company (Iraq) .

\section{Microorganisms}

Some of microorganism tested against bacteriocin activity were provided from Ibn Albetar and Ibnsina center / Industrial research and development Authority / Ministry of Industry and Minerals / Iraq and others from Food science Dept./ College of Agr. Engineering .sciences. / University of Baghdad. These microorganism were included E.coli, Staphylococcus, Salmonella, Bacillus, Candida, Lactobacillus and Bifidobacterium.

\section{Isolation of Bacillus strains}

Ten samples from different places of soil were collected from Iraqi corn and sunflower field belong to horticulture and field crops departments / College of agricultural engineering sciences / Baghdad university . In order to isolate the spore-forming bacteria, 10 $\mathrm{gm}$ of each sample of soil were suspended in $90 \mathrm{ml}$ of sterilized distilled water and heating at $80{ }^{0} \mathrm{C}$ to kill non-spore-forming bacteria . Serial dilutions were done, then $0.1 \mathrm{ml}$ of each diluents were transfered to petridish with duplicates, then BHI agar were add. After solidification, plates were incubated inverse direction under aerobic condition at 55 ${ }^{0} \mathrm{C}$ for 48 hour. Mesophiles and obligated anaerobic spore-formers bacteria will not grow at this conditions $(7,18)$. Single isolates which grown were purified by sub culturing on BHI agar. Pick up these isolates which have similar characteristics of Bacillus such as irregular edges, creamy color and somewhat sticky.

\section{Identification of Bacillus isolate}

The purified isolate that gives high growth on BHI agar at $55{ }^{\circ} \mathrm{C}$ were identified by morphological, biochemical tests and genetic analysis of $16 S$ rRNA gene sequence. The morphological tests were included a microscopic and culturing characteristics, gram stain, shap, aggregation, and spore position, while cultural characteristics of colonies were included appearance, color, edge and surface height when growth on BHI agar. Biochemical tests were included growth 
in anaerobic condition, growth at $55{ }^{\circ} \mathrm{C}$ and $15{ }^{\circ} \mathrm{C}$, catalase reaction, gelatin liquefication, starch hydrolysis, nitrate reduction, citrate utilization, Voges-proskauer reaction, acid production from glucose, xylose and 1arabinose $(7,18)$. Genetic analysis of the selected isolate was also carried out by amplification of 16S rRNA gene using PCR technique (27). Sequence of nucleotide were also analyzed in Korean Microgen Company and compared with those Genbank database in NCBI . Genetic analysis include extraction DNA of selected isolate using promega protocol and kit provided from this company. Purity of DNA extract $(1 \mu 1)$ was determined by Nanodrop spectrophotometer and absorbance at $260 \mathrm{~nm}$ and $280 \mathrm{~nm}$ were measured using following equation ( Purity of DNA extract $=$ Absorbance at $260 \mathrm{~nm} /$ Absorbance at $280 \mathrm{~nm}$ ). Amplification of $16 \mathrm{~S}$ rRNA was done using forward primer (F27) 5'AGAGTTTGATCCTGGCTCAG'3 and Reverse primer (R1492) 5'TACGGTTACCTTGTTAC GACT T'3 according to ( 27 ). Adding $12.5 \mu 1$ of Master mix , $1 \mu 1$ of these primers and $8.5 \mu l$ of nuclease free and 2ng/ $\mu \mathrm{l}$ of DNA extract . Eppendruff tube was transfer to thermocycler and following program were used : First denaturation of DNA target was carried out at $95^{\circ} \mathrm{C}$ for 5 minutes followed by second denaturation at $95^{\circ} \mathrm{C}$ for $30 \mathrm{sec}$, then primer annealing at $60{ }^{\circ} \mathrm{C}$ for $45 \mathrm{sec}$. Extension at $72{ }^{\circ} \mathrm{C}$ for $1 \mathrm{~min}$. Reaction was repeated for 30 cycles . Final extension were done at $72{ }^{0} \mathrm{C}$ for $7 \mathrm{~min}$. Finally reaction mixture was held at cooling temperature $4{ }^{0} \mathrm{C}$ for 10 minutes . PCR amplification was detected by agarose gel electrophoresis . $1 \%$ of $100 \mathrm{ml}$ agrose was prepared by dissolve $1 \mathrm{gm}$ of agrose in 100 $\mathrm{ml}$ of $1 \mathrm{X}$ TBE buffer. Mixture was heated in microwave oven for $2 \mathrm{~min}$ and $1 \mu \mathrm{l}$ of ethidium bromide $(10 \mathrm{mg} / \mathrm{ml})$ was added . Gel was poured at $50-60{ }^{0} \mathrm{C}$ in electrophoresis mold. Putting comb in gel to make samples slot and leave gel to solidification. Remove comb and add $1 \mathrm{X}$ TBE buffer to cover gel surface.Transfer $5 \mu \mathrm{l}$ of PCR product and ladder ( $100-1500 \mathrm{bp})$ provided from promega company in gel wells, then run of electrophoresis at $60 \mathrm{~mA}$ and 90 volt . Coming down of dye were noticed. Finally visualized the isolated bands under UV light . The output of amplified gene were sent to Korean Macrogen company to determine sequencing of nitrogen base and BLAST program was used (4) to compare with GenBank database of NCBI.

\section{Bacteriocin production}

production of Bacteriocin from Bacillus lichenformis HJ2020 MT192715.1 was carried out in Lurain broth ( LB) medium (Tryptone 10.0 , Yeast extract $5.0 ; \mathrm{NaCl} 5.0$ $\mathrm{g} / \mathrm{L}), \mathrm{pH}$ of medium was neutralized to 7.0 and sterilized in autoclave at $121{ }^{\circ} \mathrm{C}$ for 15 minutes at 15 pound $/$ inch $^{2}$. Two percent of Inoculum contain $1 \times 10^{6} \mathrm{CFU} \mathrm{ml}^{-1}$ of Bacillus licheniformis $\mathrm{HJ} 2020$ MT192715.1 were transfer to $250 \mathrm{ml}$ of conical flask contain 100 $\mathrm{ml}$ of sterilized LB medium and placed in shaking incubator at $37^{\circ} \mathrm{C}$ with the agitation of $150 \mathrm{rpm}$ for $48 \mathrm{hr}$. After that the cells were harvested by centrifugation at $8000 \mathrm{Xg}$ for 15 minutes at $4{ }^{\circ} \mathrm{C}$ and cell free supernatant( CFS) was considered as crud bacterocin. (19)

\section{Partially Purification of bacteriocin}

Bacteriocin as Cell Free Supernatant ( CFS ) was concentrated by precipitation using $30-70 \%$ saturation of ammonium sulphate with continuous stirring for overnight at $4{ }^{\circ} \mathrm{C}$. Precipitate was harvested by centrifugation at $6000 \mathrm{xg}$ for $15 \mathrm{~min}$ at $4^{\circ} \mathrm{C}$ and re-suspended in $25 \mathrm{ml}$ of $5 \mathrm{mM}$ phosphate buffer $\mathrm{pH} 7$, then dialyzed with phosphate buffer $0.1 \mathrm{M} \mathrm{pH}$ 7 for overnight with replacing buffer for three times using dialysis tube with $1 \mathrm{KDa}$ molecular weight cut off ( MWCO). Suspension was concentrated by dialyzing in poly ethylene glycol ( from Fluka company ). Finally concentrated bacterocin was sterilized by subjected to Millipore membrane filter ( $0.45) \mu \mathrm{m}$ and considered as partially purified bacteriocin, (19).

\section{Antimicrobial activity of bacteriocin}

Antimicrobial activity of partially purified bacteriocin was tested against several Grampositive bacteria, Gram-negative bacteria and yeast included E.coli, Staphylococcus, Salmonella, Bacillus, Lactobacillus, Bifidobacterium and Candida. These microorganisms were cultured in appropriate media and bacterocin antimicrobial activity was determined using agar well diffusion method as described by $(25,32)$. Suspension 
of these indicator isolates were adjusted to 0.5 MacFarland standard and inoculated in appropriate media. Allowed to dry and a sterile cork borer was used to made well of $6 \mathrm{~mm}$ diameter on the agar plates. Wells were filled with $50 \mu \mathrm{l}$ of partially purified bacterocin of $B$. lichenformis HJ2020 MT192715.1 . Plates were incubated for overnight at optimal temperature of test organism. After incubation, diameter of zone inhibition was measured.The activity of the bacteriocin preparation expressed in units per milliliter $(\mathrm{U} / \mathrm{ml})$ and calculated by following formula:

Antimicrobial activity of bacteriocin $(\mathrm{U} / \mathrm{ml})$ $=(1,000 / 50) \mathrm{x}$ inhibition zone diameter of highest dilution $(\mathrm{mm}) \times 1 / \mathrm{D}$

where 50 is the volume $(\mu 1)$ of utilized sample , 1000 to convert of utilized sample volume from $(\mu \mathrm{l})$ to $(\mathrm{ml})$ and $\mathrm{D}$ is the highest dilution that inhibited the growth of indicator strain at $24 \mathrm{~h}$ of incubation (10). All the experiments were performed in duplicate and results were mean of the observations.

Effects of pH, temperature and enzymes on stability of bacterocin from B.lichenformis HJ2020 MT192715.1 against Staphylocoous aureus

$\mathrm{pH}$ of partially purified bacterocin was adjusted to $(3,5,8,10$, and 12$)$, and incubated at $37^{\circ} \mathrm{C}$ for $2 \mathrm{hr}$, then readjusted to 7 with $1 \mathrm{~N}$ of $\mathrm{HCL}$ or IN of $\mathrm{NaOH}$. This step was done to determine the residual antimicrobial activity of bacteriocin using treatment of $\mathrm{pH} 7$ as control $(11,17,19)$. Also the partially purified bacteriocin solution was incubated at $5,35,50,80,100{ }^{\circ} \mathrm{C}$ for $30 \mathrm{~min}$. and at 121 ${ }^{\circ} \mathrm{C}$ for $15 \mathrm{~min}$. then cooled to room temperature and residual antimicrobial activity were determined. Partially purified bacteriocin with out heat treatment used as control at $\mathrm{pH}$ 7. To analyze sensitivity of bacterocin toward various enzymes, partially purified of bacteriocin solution was treated with $1 \mathrm{mg} \mathrm{ml}^{-1}$ final concentration of the following enzymes at $37 \mathrm{C}$ for $2 \mathrm{~h}: \alpha$-amylase . lipase , $\alpha$-chymotrypsin proteinase-K , pepsin and trypsin ( All enzymes used were from Sigma -Aldrich company ). Samples were then boiled at $100{ }^{\circ} \mathrm{C}$ for $2 \mathrm{~min}$ to denature enzymes, then cooled to room temperature and residual antimicrobial activity were determined using untreated partially purified bacteriocin as control. All treated samples were tested for residual activity against Staphylococcus aureus $1 \times 10^{6} \quad \mathrm{CFU} \mathrm{ml}^{-1}$ $(17,32)$.

\section{RESULTS AND DISCUSSION \\ Identification of isolated strain}

Fourteen isolates of Bacillus sp. from Sunflower and Corn soil samples were obtained when incubation on BHI agar at 55 ${ }^{\circ} \mathrm{C}$. The isolate $\mathrm{C} 4$ was revealed a highest growth density on BHI agar in comparison with other isolates Table(2).

Table 1. Corn and sunflower soil isolates
growth on BHI agar at 55 ' C / 48 hr
\begin{tabular}{|lcll|}
\hline Strain & Growth & Strain & Growth \\
from & density & $\begin{array}{l}\text { from } \\
\text { sunflower } \\
\text { corn soil }\end{array}$ & density \\
& & soil & \\
\hline C1 & + & S1 & ++ \\
C2 & + & S2 & + \\
C3 & ++ & S3 & + \\
C4 & +++ & S4 & ++ \\
C5 & + & S5 & + \\
C6 & ++ & S6 & + \\
C7 & + & S7 & ++ \\
\hline
\end{tabular}

Preliminary identification of isolate $\mathrm{C} 4$ was based on its morphological and biochemical characteristics according to Bergey's Manual of Systematic Bacteriology. Isolate C4 revealed white-creamy colony with irregular edge when growth on BHI agar at $55{ }^{0} \mathrm{C}$. Arrangements of colonies were bilateral or separate groupings . Morphological test of C4 isolate revealed that this isolate was gram positive and motile, it seem to be elliptical cylinderical shape and endospore forming was central position. These results were agree with (23).Biochemical test of isolate $\mathrm{C} 4$ revealed that this isolate can able to hydrolyze starch, catalase positive, gelatin liquefaction was positive and can grow at 15 and $55^{\circ} \mathrm{C}$ (Table 3). 
Table 2 . Morphological and Biochemical test of isolate $\mathrm{C} 4$

\begin{tabular}{|c|c|}
\hline \multicolumn{2}{|c|}{ Morphological } \\
\hline Test & Result \\
\hline Shape & Elliptical -cylinderical \\
\hline Arrangements & $\begin{array}{c}\text { Bilateral or separate } \\
\text { groupings }\end{array}$ \\
\hline Gram reaction & + \\
\hline Endospore formation & Central \\
\hline Colony color & White - creamy \\
\hline Motility & + \\
\hline \multicolumn{2}{|c|}{ Biochemical } \\
\hline Test & Result \\
\hline Catalase & + \\
\hline Gelatin liquefaction & + \\
\hline Starch hydrolysis & + \\
\hline Nitrate reduction & + \\
\hline Citrate utilization & + \\
\hline Voges-proskauer & + \\
\hline \multicolumn{2}{|l|}{ Acid production from } \\
\hline D-glucose & + \\
\hline D-xylose & + \\
\hline L-arabinose & + \\
\hline Growth in anaerobic agar & + \\
\hline Growth at $55^{\circ} \mathrm{C}$ & + \\
\hline Growth at $15^{\circ} \mathrm{C}$ & + \\
\hline
\end{tabular}

$1500 \mathrm{bp}$

1

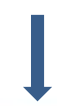

These results were agree with $(7,18)$, where they pointed out the general characterizations of Bacillus genes and revealed that this isolate belong to $B$. lichenformis according to (12). Moreover genetic analysis was achieved depending upon identification of $16 \mathrm{~S}$ rRNA gene, Firstly the extraction of DNA for selected isolate $\mathrm{C} 4$ has been done and the purity was determined by measure the ratio of absorbance at $260 \mathrm{~nm}$ to absorbance at $280 \mathrm{~nm}$. Therefore the purity of DNA extract of isolate $\mathrm{C} 4$ attained to 1.9 . This result conforms with many studies which pointed out that the purity of DNA extraction for prokaryote was considered highly purified if the ratio of absorbance at $260 \mathrm{~nm}$ to absorbance at $280 \mathrm{~nm}$ was equal $\geq 1.8$ (31). Then amplification of 16S rRNA gene by PCR technique was achieved. Results of electrophoresis were revealed that there is a single band of amplified gene(Fig1). 1500bp

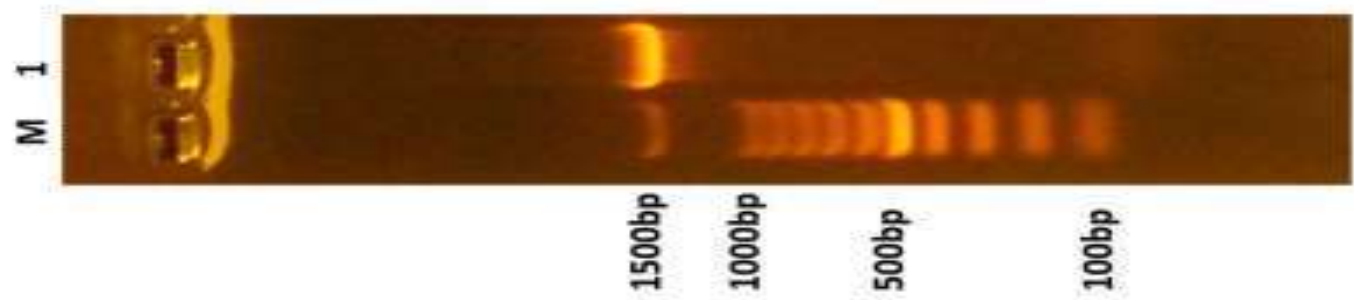

Fig 1. PCR amplification product of $16 \mathrm{~S}$ rRNA gene on $1 \%$ agrose for isolate $\mathrm{C4}$, Lane M: ladder (100bp); lane 1 sample

This result indicate a successful engagement of primers with gene target 16S rRNA with out other parts of DNA . Molecular weight of amplicon was determined and attained to about 1500 bp ( Fig 1 ) .Many studies point out using gene $16 \mathrm{~S}$ rRNA with successfully for identification of many species of bacteria and it gives a decisive results $(1,26)$. Another study (3) indicate length of amplified target (16S rRNA) of Bacillus licheniformis attained to $1.4 \mathrm{Kbp}$, While (28) found molecular weight of amplified gene of 16S rRNA for Bacillus sp. were $1082 \mathrm{bp}$ and (13) pointed that molecular weight of $16 \mathrm{~S}$ rRNA of Bacillus subtilis ZHR( GenBank no. MG735442.1) were 1150 bp after trimmed some of low quality sequences especially irregular peaks . Also (14) indicated that molecular weight of 16S rRNA of Bacillus subtilis MH049477.1 was 1265 bp. Differences in molecular weight of amplified gene for $16 \mathrm{~S}$ rRNA may be due to differences between sources of isolates, Moreover differences between DNA extraction protocol or program conditions which used in PCR technique (26). Products of PCR amplification and primers were sent to Macrogen company to study sequence of nucleotides for $16 \mathrm{~S}$ rRNA gene. Results revealed that sequence of $16 \mathrm{~S}$ rRNA gene contain 1415 nucleotide after trimmed some of sequences which had low quality especially irregular peaks (Table 3 ). Formation of these parts may be due to primers fusion or it represent short results of amplification which disappeared during electrophoresis on agarose gel . Alignment of 
this sequence through matching with reported 16S rRNA gene sequences in NCBI Genbank using BLAST program showed that isolate $\mathrm{C} 4$ have similar sequence with $100 \%$ to those sequences of more than 20 strain of Bacillus licheniformis (Table 4). For this reason the local isolate $\mathrm{C} 4$ was considered belong to Bacillus lichenformis and given a strain name HJ2020 with accession number MT192715.1 according to Genbank data base of NCBI.

Table 3. The sequence of nucleotides (FASTA ) of $16 \mathrm{~S} r R N A$ gene for isolate $\mathrm{C4}$

\begin{tabular}{|c|c|c|}
\hline Gene & Sequencing of $16 S r R N A$ ( FASTA Sequencing ) & $\begin{array}{c}\text { Total } \\
\text { nitrogen base }\end{array}$ \\
\hline $\begin{array}{c}\text { 1_27F } \\
\text { 16SrRNA }\end{array}$ & $\begin{array}{l}\text { GTCGAGCGGACCGACGGGAGCTTGCTCCCTTAGGTCAGCGGCGGACGGGTGAG } \\
\text { TAACACGTGGGTAACTGCCTGTAAGACTGGGATAACTCCGGGAAACCGGGGCT } \\
\text { AATACCGGATGCTTGATGAACCGCATGGTTCAATCATAAAAGGTGGCTTTAGC } \\
\text { TACCACTTACAGATGGACCCGCGGCGCATTAGCTAGTTGGTGAGGTAACGGCTC } \\
\text { ACCAAGGCGACGATGCGTAGCCGACCTGAGAGGGTGATCGGCCACACTGGGACT } \\
\text { GAGACACGGCCCAGACTCCTACGGGAGGCAGCAGTAGGGAATCTTCCGCAATGG } \\
\text { ACGAAAGTCTGACGGAGCAACGCCGCGTGAGTAAGAAGGTTTCGGATCGTAA } \\
\text { AACTCTGTTGTAGGGAAGAACAAGTACCGTTCGAATAGGGCGGTACTTGACG } \\
\text { GTACCTAACCAGAAAGCCACGGCTAACTACGTGCCAGCAGCCGCGGTAATACGT } \\
\text { AGGTGGCAAGCGTTGTCCGGAATTATTGGGCGTAAAGCGCGCGCAGGCGGTTTC } \\
\text { TTAAGTCTGATGTGAAAGCCCCGGCTCAACCGGGGAGGGTCATTGGAAACTGG } \\
\text { GGAACTTGAGTGCAGAAGAGGAGAGTGGAATTCCACGTGTAGCGGTGAAATGCG } \\
\text { TAGAGATGTGGAGGAACACCAGTGGCGAAGGCGACTCTCTGGTCTGTAATGAC } \\
\text { GCTGAGGCGCGAAAGCGTGGGGAGCGAACAGGATTAGATACCCTGGTAGTCCAC } \\
\text { GCCGTAAACGATGAGTGCTAAGTGTTAGAGGGTTTCGGCCTTTAGTGCTGCAG } \\
\text { CAAACGCATTAAGCACTCCGCCTGGGGAGTACGGTCGCAAGACTGAAACTCAAA } \\
\text { GGAATTGACGGGGGCCCGCACAAGCGGTGGAGCATGTGGTTAATTCGAAGCAA } \\
\text { CGCGAAACCTTACCAGGTCTTGACATCCTCTGACAACCCTAGAGATAGGGCTTCC } \\
\text { CCTTCGGGGGCAGAGTGACAGGTGGTGCATGGTTGTCGTCAGCTCGTGTCGTGA } \\
\text { GATGTTGGGTTAAGTCCCGCAACGAGCGCAACCCTTGATCTTAGTTGCCAGCATT } \\
\text { CAGTTGGGCACTCTAAGGTGACTGCCGGTGACAAACCGGAGGAAGGTGGGGATG } \\
\text { ACGTCAAATCATCATGCCCCTTATGACCTGGGCTACACACGTGCTACAATGGGCA } \\
\text { GAACAAAGGGCAGCGAAGCCGCGAGGCTAAGCCAATCCCACAAATCTGTTCTCA } \\
\text { GTTCGGATCGCAGTCTGCAACTCGACTGCGTGAAGCTGGAATCGCTAGTAATCG } \\
\text { CGGATCAGCATGCCGCGGTGAATACGTTCCCGGGCCTTGTACACACCGCCCGTC } \\
\text { ACACCACGAGAGTTTGTAACACCCGAAGTCGGTGAGGTAACCTTTTGGAGCCAG } \\
\text { CCGCCG }\end{array}$ & 1415 bp \\
\hline
\end{tabular}

Table 4. Ratio of similarity of local isolate C4 with Bacillus strains in NCIB - blasted record

\begin{tabular}{|cllcc|}
\hline Item & Strain & Identi. \% & Accession \\
\hline 1 & Bacillus licheniformis strain HJ2020 16S ribosomal RNA gene,partial sequence & 100 & MT192715.1 \\
2 & Bacillus licheniformis strain ANA17 16S ribosomal RNA gene, partial sequence & 100 & MT122807.1 \\
3 & Bacillus licheniformis strain LXJ95 16 S ribosomal RNA gene, partial sequence & 100 & MN746177.1 \\
4 & Bacillus licheniformis strain CGZ927 16S ribosomal RNA gene, partial sequence & 100 & MN900518.1 \\
5 & Bacillus licheniformis strain P8_B2 chromosome, complete genome & 100 & CP045814.1 \\
6 & Bacillus licheniformis strain MDSp5 16S ribosomal RNA gene, partial sequence & 100 & MN493794.1 \\
7 & Bacillus licheniformis strain BioE-BL11 16S ribosomal RNA gene, partial sequence & 100 & MN493718.1 \\
8 & Bacillus licheniformis strain strain KNU11 chromosome, complete genome & 100 & CP042252.1 \\
9 & Bacillus licheniformis strain HN-5 16S ribosomal RNA gene, partial sequence & 100 & MK648261.1 \\
10 & Bacillus licheniformis strain CLMTCHB29 16S ribosomal RNA gene, partial sequence & 100 & MH197076.2 \\
11 & Bacillus licheniformis strain PB3 chromosome, complete genome & 100 & CP025226.1 \\
12 & Bacillus licheniformis strain UN1 16S ribosomal RNA gene, partial sequence & 100 & MK088263.1 \\
13 & Bacillus licheniformis strain D4-10-2-2 16S ribosomal RNA gene, partial sequence & 100 & MK063871.1 \\
14 & Bacillus licheniformis strain D4-10-1-3 16S ribosomal RNA gene, partial sequence & 100 & MK063868.1 \\
15 & Bacillus licheniformis strain BRM043913 16S ribosomal RNA gene, partial sequence & 100 & MH305328.1 \\
16 & Bacillus licheniformis strain HTI601-1 16S ribosomal RNA gene, partial sequence & 100 & MG835984.1 \\
17 & Bacillus licheniformis strain NYL26 16S ribosomal RNA gene, partial sequence & 100 & MG833400.1 \\
18 & Bacillus licheniformis strain Sohag3 16S ribosomal RNA gene, partial sequence & 100 & MH605438.1 \\
19 & Bacillus licheniformis strain MGYG-HGUT-02357 genome assembly, chromosome & 100 & LR698983.1 \\
20 & Bacillus licheniformis strain T7 16S ribosomal RNA gene, partial sequence & 100 & MH000674.1 \\
\hline
\end{tabular}

Antimicrobial activity of bacterocin

Inhibitory spectrum of bacteriocin was determined by agar well-diffusion according to method of (25) against different indicator strains (Table 5). Results were revealed that the Inhibitory activity was attained to 220 
and $360 \mathrm{U} \mathrm{ml}^{-1}$ against to pathogenic strains, including clinical isolates of Escherichia coli and Salmonella typhi respectively, while it attained to 42,60 , and $80 \mathrm{U} / \mathrm{ml}$ against to B.subtilis, B. cereus and Candida albican respectively. The differences of mode of action of bacteriocin on microorganisms may be attributed to it's effect on cell membranes permeability or integrity which was disrupted and caused leakage of intracellular components including $\mathrm{Na}+\mathrm{K}+\mathrm{ATP}, \mathrm{AKP}$, nucleic acids and proteins (33) or may be due bactericidal and cytoxicity effect of bacterocin which lead to kill the cell according to type of microorganism (30). Results also revealed that there is no activity was detected against Lactobacillus and Bifidobacterium which were generally recognized as beneficial bacteria or safe bacteria. These results were similar to those shown by $B$. licheniformis $\mathrm{P} 40$ (8).

\section{Table 5. Inhibitory spectrum of bacteriocin} from Bacillus licheniformis toward some of microorganism

\begin{tabular}{|lc|}
\hline \multicolumn{1}{|c|}{ Indicator strain } & Activity $\left(\mathrm{U} \mathrm{ml}^{-1}\right)$ \\
\hline Escherichia coli $0157: \mathrm{H} 7$ & $\mathbf{2 2 0}$ \\
Staphylococcus aureus & $\mathbf{3 6 0}$ \\
Salmonella typhi & $\mathbf{2 0 0}$ \\
Pseudomonas aeroginosa & 233 \\
Bacillus cereus & $\mathbf{6 0}$ \\
Candida albicans & $\mathbf{8 0}$ \\
Lactobacillus plantarum & $\mathbf{0 . 0}$ \\
Bifidobacterium befidie & $\mathbf{0 . 0}$ \\
Bacillus subtilis & $\mathbf{4 2}$ \\
\hline
\end{tabular}

Effects of $\mathrm{pH}$, temperature and enzymes on stability of bacterocin from Bacillus lichenformis

\section{HJ2020MT192715.1againstStaphylocoousau} reus

The stability of partial purified of bacteriocin produced from Bacillus licheniformis HJ2020
MT192715.1 was tested with different values of $\mathrm{pH}$, temperature and sensitivity toward several proteolytic enzymes, Moreover $\alpha$ amylase and lipase against Staphylococcus aureus with density of $1 \times 10^{6} \mathrm{CFU} \mathrm{ml}^{-1}$. Results were summarized in Table (6). Bacteriocin was loss about $25-40 \%$ of it's activity when incubated in acidic $\mathrm{pH}$ between (3-5), while it lost about $80 \%$ of it's activity at $\mathrm{pH} 10$ and there is no activity at $\mathrm{pH} 12$. These results were agree with (21) which pointed that the activity of bacteriocins was completely disappeared at pH 12 and (16) was suggested that the bacteriocin activity affected by $\mathrm{pH}$ and disappeared at $\mathrm{pH}$ 9. Heat stability of bacterocin also was tested and the results show that it retained all activity when incubated at $5-35{ }^{\circ} \mathrm{C}$ for $30 \mathrm{~min}$. while it loss about $25-50 \%$ of it's activity after incubation at $50-80{ }^{\circ} \mathrm{C}$ and loss all activity when incubated at $100^{\circ} \mathrm{C} / 30 \mathrm{~min}$ or treated with autoclave at $121{ }^{\circ} \mathrm{C}$ for $15 \mathrm{~min}$ at 15 psi. Reduction of bacteriocin activity and lost all of it's activity at high temperature attributed to denaturation will occur for proteinaceous nature of bacterocin (6). Results also revealed that bacteriocin was stable when treated with $\alpha$ - amylase and lipase because that bacteriocine might not contain glycosidic or lipidic structure, So these enzymes (glycosidaeses and lipases ) have no effect on proteinaceous nature of bacterocine (29). While it sensitive to proteolytic enzyme and lost about $10-50 \%$ of it's activity when treated with these enzymes Table (6). These results confirm once again that this bacteriocin from Bacillus licheniforims HJ2020 MT192715.1 is proteinaceous nature and this agree with $(5,11,17)$.

Table 6. Effects of pH, Temperature and Enzymes on antimicrobial activity of bacteriocin

from Bacillus licheniformis HJ2020 MT192715.1 against Staphylococcus aureus

\begin{tabular}{|ccccccc|}
\hline Treatments & pH & $\begin{array}{c}\text { Residual } \\
\text { activity \% }\end{array}$ & \multicolumn{1}{c}{ Temperature } & $\begin{array}{c}\text { Residual } \\
\text { activity } \%\end{array}$ & Enzyme & Residual \\
activity $\%$
\end{tabular}

\section{ACKNOWLEDGMENTS}

Authors are thankful to Ibn-betar and Ibnsin center / Industrial research and development Authority / Ministry of industry and minerals for supporting in supplying some of standard microorganism and performing some of Bioactivity tests of bacterocin . 


\section{REFERENCES}

1-Aarti C . and A. Khusro, .2015. Discovery of polygalacturonase producing Bacillus tequilensis strain armati using $16 \mathrm{~S}$ rRNA gene sequencing. Asian J Pharm Clin Res, 8 ( Issue 5) : 58-62

2-Anthony T, T. Rajesh.,N. Kayalvizhi and P.Gunasekaran . 2009 . Influence of medium components and fermentation conditions on the production of bacteriocin (s) by Bacillus licheniformis AnBa 9 . Bioresour. Technol., $100: 872-877$

3- Anuraj N.S.1 , M.K. Sabnani , Y. Mukesh, K. Jyotsana , S. Deepika , C. Rachna and S. Jyoti. 2012. .Identification and characterization of proteases and amylases producing Bacillus licheniformis strain embs026 by 16 s rRNA gene sequencing. International Journal of Microbiology Research . 4 ( 5 ): $231-235$

4-Benson, D.A., I. Karsch-Mizrachi, K. Clark, K., D.J. Lipman, J. Ostell, and E. Sayers , . 2002. Nucleic Acids Res., 40 , D48-D53

5-Bizani D and A. Brandelli . 2002. Characterization of a bacteriocin produced by a newly isolated Bacillus sp. strain 8A. J. Appl. Microb. 93: 512-519

6-Bizani D, A. Dominguez and A. Brandelli .2005. Purification and partial chemical characterization of the antimicrobial peptide cerein 8A .Letters in Applied Microbiology 41(3):269 - 273

7-Buchanan R.E. and N.M.Gibbons . 1974. Bergeys manual of Determinative bacteriology, 8th Edition. The Williams and Wilkins Company / Baltimore. page : 531533

8- Cladera-Olivera F, GR .Caron and A. Brandelli A . 2004. Bacteriocin-like substance production by Bacillus licheniformis strain P40. Lett. Appl. M. 38: 251-256

9-Edward H., J.R. Burtt and M.I.Jann. 1999. Occurrence of feather-degrading Bacilli in the plumage of birds. Auk 116 (2) :364-372

10-Farias, M. E. , A.A. Holgado, and F. Sesma. .1994. Bacteriocin production by lactic acid bacteria isolated from regional cheeses: inhibition of food borne pathogens. J. of Food Protection, 57( 11) : 1013-1015

11- Florencia C.A, G.R. Caron and B. Adriano. 2004. Bacteriocin-like substance production by Bacillus licheniformis strain
P40. Letters in Applied Microbiology 38 (4) : 251-256

12-Garrity, G. M.,J.A. Bell and T. Lilburn. .2005. The revised road map to the manual. In Bergey's Manual ${ }^{\circledR}$ of Systematic Bacteriology pp.:159-187 Springer US

13-Hassan Z.A ; A.J. Hameed and N.J Rebah 2018 .Cloning and expression of laccase gene produced from Bacillus subtilis ZHR MG735442.1 in E. coli .Iraqi Journal of Agricultural Sciences ,49 (5) :546- 553

14- Jebur H. A. and A.H. Lena . 2018 . Isolation, Screening, and Identification of Bacillus sp. ProducedL- Glutaminase and Optimization of its Production by Submerged Fermentation. Journal of Global Pharma Technology|,10 (Issue 11 ) : 737-743

15- Jingping G., Y. Sun, X. Xin, Y. Wang and W. Ping . 2016 . Purification and Partial Characterization of a Novel Bacteriocin Synthesized by Lactobacillus paracasei HD17 Isolated from Chinese Sauerkraut Juice , Scientific Reports 6:19366

16-Kayalvizhi N and P. Gunasekaran 2008. Production and characterization of a lowmolecular-weight bacteriocin from Bacillus licheniformis MKU3 Lett Appl. Microbiol., 47: 600-607

17-Kong B. 1., P. Marilen, I. Balolong ,H.K. Sang ,1.O. Kyoung and K. Dae-Kyung Kang .2016. Isolation and Characterization of a Broad Spectrum Bacteriocin from Bacillus amyloliquefaciens RX7. Hindawi Publishing Corporation BioMed Research International Volume, Article ID 8521476

18-Logan, N.A. and P. De Vos, . 2009. Genus Bacillus in : Bergeys Manual of Systematic Bacteriology, 2nd, Vol.3, springer Dordrecht Heidelberg London New york, pp: 32- 128

19- Maria T., F. Ilias ,K. Gerda and M. Antigoni . 2012 . Partial purification and characterization of a bacteriocin produced by Bacillus subtilis NCIMB 3610 that exhibits antimicrobial activity against fish pathogens. Journal of Biological Research-Thessaloniki 18: $310-319$

20- Maria G., A. Asma., A. Afsheen, R.Z. Rashida , N. Nadir.and A. Shah A. 2013. Isolation and characterization of different strains of Bacillus licheniformis for the production of commercially significant enzymes. Pak. J. Pharm. Sci., 26 (4) :691-697 . 
21-Marwa A. S. , H. M. Abdelsamei1, E. M. Ibrahim1, A. M. Abdou1 and S. A. ElSohaimy. 2015. Effect of $\mathrm{pH}$, heat treatments and proteinase $\mathrm{K}$ enzyme on the activity of Lactobacillus Acidophilus bacteriocin. Benha veterinary medical journal, 28 ( 1 ) : 210-215 22 - Naclerio G, E. , E. Ricca, M. Sacco and M. Felice. 1993. Antimicrobial activity of a newly identified bacteriocin of Bacillus cereus. Appl Environ Microbiol, 59 :43134316

23-Nicholson, W.L. 2002. Roles of Bacillus endospores in the environment. Cell Mol. Life Sci. , $59: 410-416$

24-Pattnaik P, JK. Kaushik,S. Grover and VK.Batish. 2001 .Purification and characterization of a bacteriocin-like compound (Lichenin) produced anaerobically by Bacillus licheniformis isolated from water buffalo, J. Appl. Microbiol., 91: 636-645

25- Ramachandran R., A.. Chalasani , R. Lal and U.Roy . 2014.A broad-spectrum antimicrobial activity of Bacillus subtilis RLID 12.1," Scientific World Journal Article ID 968487, 10 pages

26- Rehman HU, S.A. Qader and A. Aman.2012. Polygalacturonase: production of pectin depolymerising enzyme from Bacillus licheniformis KIBGE IB. Carbohydrate polymer. , 90 (1) :387-391

27-Shriparna M. ; K.Dhananjay , K.N.Ashis C.and Ranadhir . 2013. 16S rRNA gene sequence analysis of the metagenome derived from water of river Mahananda at Siliguri , Indian Journal of Biotechnology . 12:80-87
28 - Salman T., M.Kamal, M.Ahmed, SM. Siddiqa , RA.Khan and A. Hassan. 2016. Medium optimization for the production of amylase by Bacillus subtilis RM16 in Shakeflask fermentation. Pakistan Journal of Pharmaceutical Sciences 29 (2) : 439-444

29- Seyma S. K.,S. Ali and S. Elif .2014. Production and characterization of bacteriocinlike peptide produced by Bacillus amyloliquefaciens B10. Sevim ve ark., Erciyes Üniversitesi 30(5) :338-345

30- Sharma G., D. Shweta ,G. Sanjay and G. Reema .2018. Antibacterial Activity, Cytotoxicity, and the Mechanism of Action of Bacteriocin from Bacillus subtilis GAS101. . Medical Principles and Practice 27:186-192 31-Turner, P., A. McLennan , A. Bates and M. White. 2005. Molecular Biology, 3rd edition: Taylor and Francis Ltd

32-Xie , J. 2009. "Isolation and characterization of a bacteriocin produced by an isolated Bacillus subtilis LFB112 that exhibits antimicrobial activity against domestic animal pathogens." African Journal of Biotechnology, 8 ( 20): 5611-5619

33- Xinran L., L. Miao, M. Huanhuan, B. Fengling, L. Yang, S. Mengtong, and L. Jianrong.2018. Purification , characterization and action mechanism of plantaricin JY22, a novel bacteriocin against Bacillus cereus produced by Lactobacillus plantarum JY22 from golden carp intestine. Food Sci Biotechnol. 27(3): 695-703 